http://dx.doi.org/10.1590/0370-44672018720098

Tennison Freire Souza Jr., Sidnei Helder Cardoso Teixeira ${ }^{3,5}$

https://orcid.org/0000-0002-3522-1706

${ }^{1}$ Universidade Federal do Paraná - UFPR, Centro de Estudos de Engenharia Civil - CESEC, Curitiba - Paraná - Brasil.

${ }^{2}$ Universidade Federal do Rio Grande do Sul - UFRGS Programa de Pós-Graduação em Engenharia Civil PPGEC, Porto Alegre - Rio Grande do Sul - Brasil.

${ }^{3}$ Universidade Federal do Paraná - UFPR, Departamento de Construção Civil - DCC, Curitiba - Paraná - Brasil

E-mails: ${ }^{4}$ tennisonufpr@outlook.com, 5sidnteix@outlook.com

\section{Simulation of tailings release in dam break scenarios using physical models}

\begin{abstract}
This article presents an experimental study performed to evaluate the volume of material released from the reservoir during a tailings dam failure event using models. To verify the influence of the parameters related to the breach geometry and the undrained shear strength $(\mathrm{Su})$ in a failure event, 20 scenarios were simulated considering the absence of water in the reservoir. The material used to simulate tailings was bentonite, due to the similarity between the properties of the mud and mineral tailings sludge. Geometry and undrained shear strength were adjusted considering a scale factor of 1: 500. Regarding the studied parameters, the geometry of the breach was based on data from literature, whose lateral slopes were $0.50 \mathrm{H}: 1 \mathrm{~V}, 0.51 \mathrm{H}: 1 \mathrm{~V}$ and 0.5467 $\mathrm{H}: 1 \mathrm{~V}$ in the trapezoidal breaches and 1: $1(\mathrm{~L} / \mathrm{H}=0.97)$ and $1: 1(\mathrm{~L} / \mathrm{H}=1.1)$ in the rectangular ones. The undrained shear strength ranged from 0.030 to $0.20 \mathrm{kPa}$. The results allowed to conclude that the mobilization of material increases with the average aperture width of the trapezoidal breach, being this the distinct behavior in rectangular breaches. Although the rectangular breaches had smaller average widths compared to the trapezoidal breaches, their base widths were larger and it is possible to infer that the mobilized volume depends on the geometry and the average width of the breach.
\end{abstract}

Keywords: mine tailing; dam break; breach failure; physical model.

\section{Introduction}

The mining activity generates millions of cubic meters of materials extracted and handled in the beneficiation process each year. In the case of tailings, the produced amount depends on the used process for extraction, the ore concentration and the deposit location. The quantification of this material is complex, due the diversity of operations and technologies used in the extraction and processing technics. According to Portal Brasil (2014), during 2013 in Brazil, the share of mineral goods in exports was $23.5 \%$. In the GDP (Gross Domestic Product) of the mineral sector, which was U\$ 85 billion, the mineral assets represented participation of around $4 \%$ in the national GDP.
Among the alternatives for disposing tailings, miners frequently have chosen to construct dams and store tailings in their reservoirs. However, if the dams are inadequately built or designed, these structures represent a great risk to society, to the environment and to the economy. Generally, these materials raise uncertainties regarding their mechanical behavior, either due to the low shear strength or the variable permeability. Therefore, continuous monitoring of the material throughout the construction and operational process is necessary.

For water retention dams, the dam break evaluations are performed using the hydrodynamic approach, whose focus is on understanding the potential effect of flooding through parameters such as velocities and maximum discharges. However, this approach is inappropriate for tailings dams, due to the existence of physical properties other than the upstream material compared to water reservoirs, so it is necessary to understand the mass mobilization behavior of the mineral tailings using a geotechnical approach, which is a more realistic assessment of the phenomenon.

The objective of this research was to develop a theoretical / empirical study to evaluate the released volume of tailings in dam failure scenarios using bentonite as the contained material to simulate the conventional mineral tailings. 


\section{General aspects of tailings dams}

The tailing dams (See Figure 1) represent artificial retention barriers for containing mineral waste from ore beneficiation. In general, these structures are commonly initiated by constructing a starting dam with mining waste, tailings or compacted

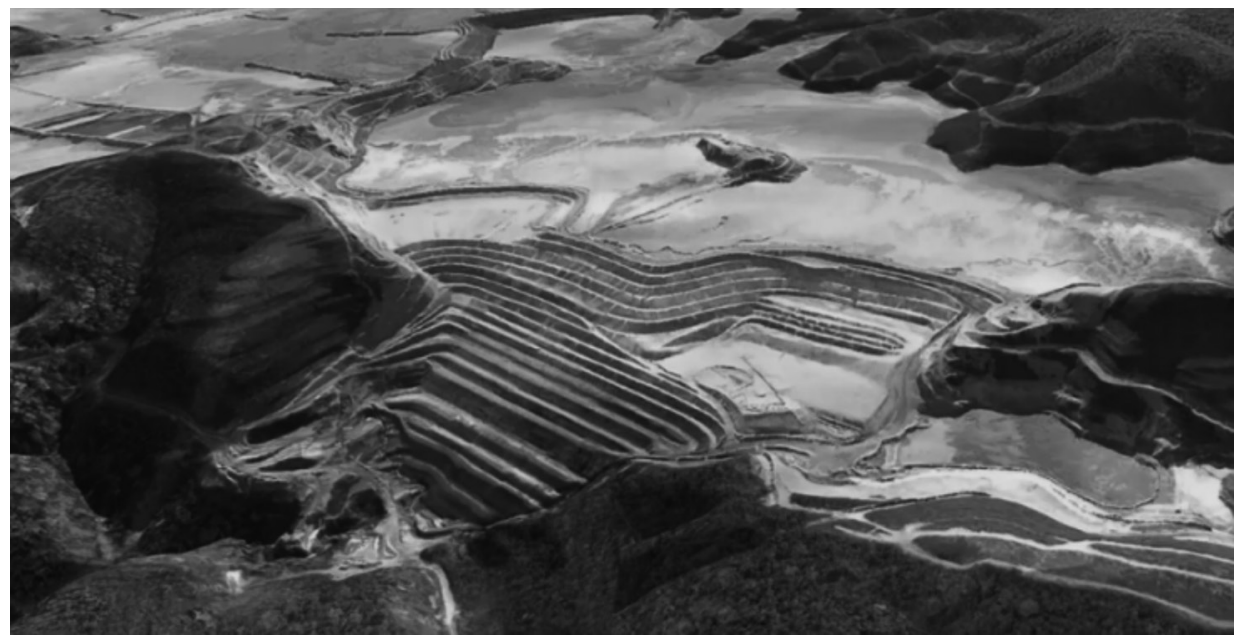

According to ANA (2017), there are 839 tailings dams in Brazil, representing $3.66 \%$ of dams worldwide. These dams are mainly susceptible to slope instabilities, overtopping, and earthquakes (ICOLD, 2001). Rico et al. (2008) cited that $83 \%$ of failures occurred in inactive dams, $15 \%$ in active dams and two percent occurred in inactive but maintained dams. In addition, in the same studies, $55.9 \%$ of the incidents occurred in dams with more than $15 \mathrm{~m}$ depth and $22.6 \%$ in dams soil. Once the structure is constructed, the pulp is released in the upstream side of the dam by pumping the tailings according to the beneficiation technics of the ore. The tailings are hydraulically deposited from the crest of the starting dike, to form a tailings beach. Currently three constructive methods are highlighted: upstream method; downstream method; centerline method. Besides these, there is the mixed method that represents the mixture between the traditional methods of construction.
Figure 1

Fundão dam in 2015

in the municipality of Mariana- MG.

Source: Minning (2018)

in literature. Figure 2 illustrates an example of failure of the Marriepsruit dam in the suburb of Virginia in South Africa caused by the rains in the region. Davies (2002) cited a worldwide inventory of 3,500 known tailings dams in the last 30 years (1970 to 2001) of two to five faults per year, which is equivalent to an annual probability between one in 700 and one in 1750 . This failure rate does not provide a favorable comparison with less than one in 10,000 that appears to represent conventional dams.

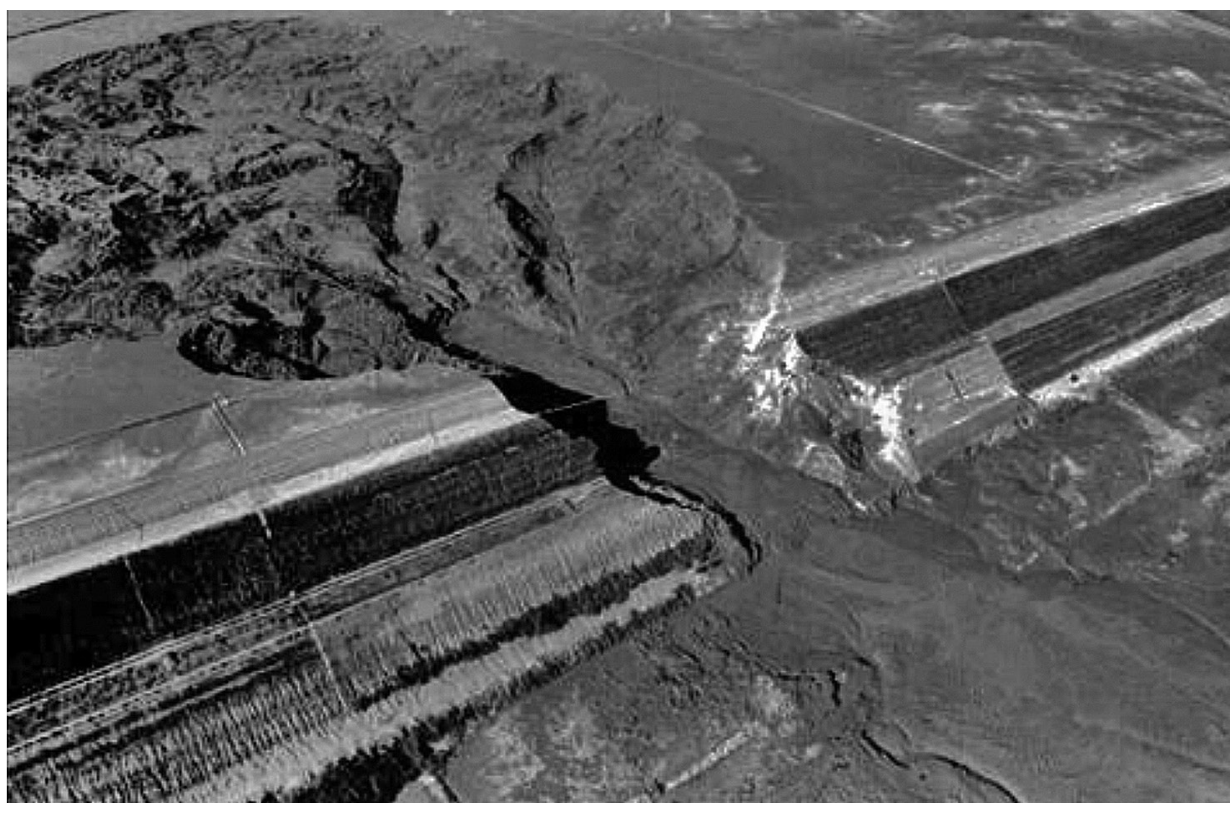

Figure 2

Rupture of the Marriespruit tailings dam in Virginia-South Africa, 1994. Source: Flood List (2018) 


\section{Materials and methods}

For the research presented herein, the material used in substitution for the

Table 1

Physical characterization of bentonite.

Regarding the reading equipment (see Figure 3) of the post-rupture relief, it consists of: a) computer with $\mathrm{MyCam}^{\circledR}$ software; b) simulator box with cracks in wood; c) metal structure as a base for the

Figure 3

Physical model with laser triangulation reading system.

To define the lateral slope walls adopted in the study, the researches of MacDonald and Langridge-Monopolis (1984), by Froelich (2008) and Brunner (2014) were considered. According to MacDonald and Langridge (1984),

Table 2

Geometry of rupture breaches adopted.

In order to understand the behavior of the released volume, the technique of topographic survey using the laser triangulation method was used. With this technique, as there are variations tailings was bentonite due to its strength and rheological characteristics being similar to mineral tailings whose physical characteristics are presented in Table 1.

\begin{tabular}{c|c|c} 
Properties & Standard & Values \\
\hline Solid unit mass & DNER-ME 093/94 & $2.40 \mathrm{~g} / \mathrm{cm}^{3}$ \\
\hline Total Unit Mass & NBR NM 45:2006 & $0.86 \mathrm{~g} / \mathrm{cm}^{3}$ \\
\hline Hygroscopic Moisture Content & DNE-ME 213/94 & $13.96 \%$ \\
\hline Plasticity Limit & NBR 7180:2016 & $65.28 \%$ \\
\hline Liquidity limit & NBR 6459:2016 & $455.94 \%$ \\
\hline Laser Granulometry Test & --- & ---- \\
\hline
\end{tabular}

reading support with fixed and movable planks; d) five Megapixels webcam with 640 x 480 image resolution; and e) linear scanning laser.

The simulation box was designed with the geometry of $40 \mathrm{~cm} \times 50 \mathrm{~cm} \times 60$ $\mathrm{cm}$ (width, length and height) being filled up to $15 \mathrm{~cm}$ in height relative to the base of the same to simulate a tailings dam scale 1: 500, i.e. with a height of $75 \mathrm{~m}$, without water.

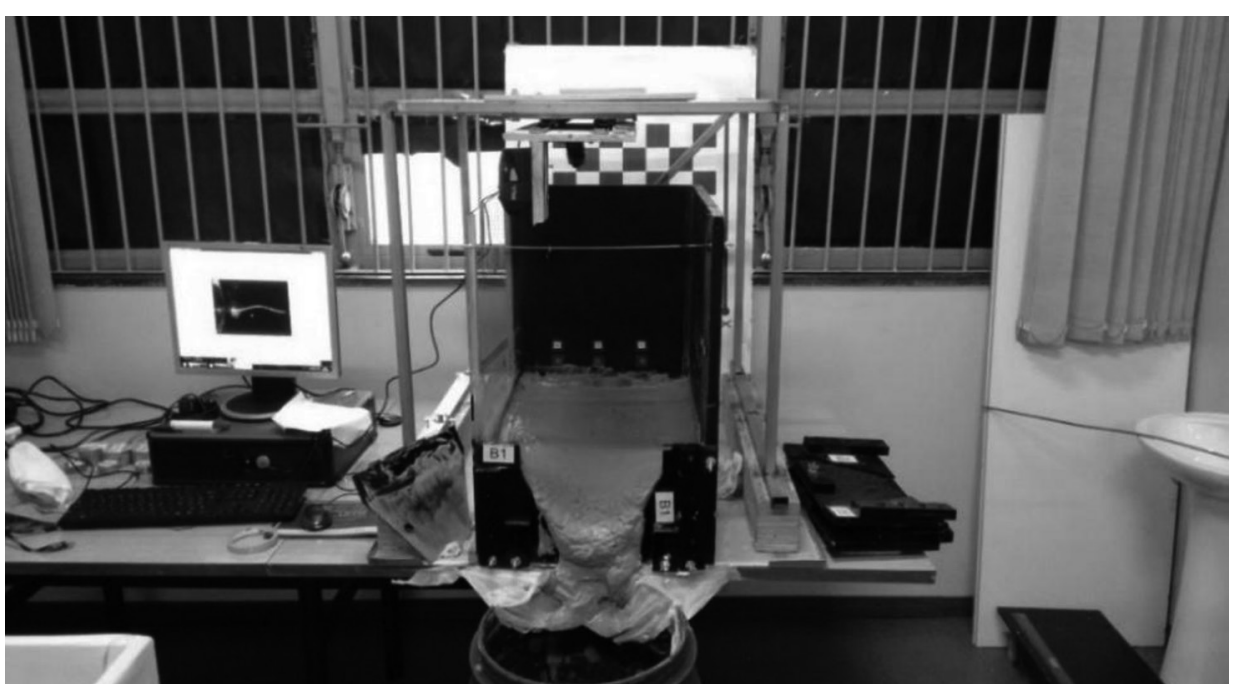

the breach has a trapezoidal shape with lateral slopes of $0.5 \mathrm{H}: 1 \mathrm{~V}$, whereas Froelich (2008) cited that the lateral slope of breaches opened by a piping mechanism is $0.7 \mathrm{H}$ : $1 \mathrm{~V}$. Brunner (2014) stated based on FERC notes that dross and tailings dams reach 1: 1 or 2: 1 lateral slopes. In this manner, lateral wall slopes of breaches of $0.50 \mathrm{H}: 1 \mathrm{~V}$, $0.51 \mathrm{H}: 1 \mathrm{~V}, 0.5467 \mathrm{H}$ : $1 \mathrm{~V}$ and $1 \mathrm{H}: 1 \mathrm{~V}$ were adopted. Additional information of breaches is shown in Table 2 .

\begin{tabular}{c|c|c|c|c|c} 
Geometry & B1 & B2 & B3 & B4 & B5 \\
\hline Breach Height $(\mathrm{cm})$ & 15.00 & 15.00 & 15.00 & 14.50 & 16.50 \\
\hline Bottom width $(\mathrm{cm})$ & 9.70 & 9.70 & 11.60 & 14.50 & 16.50 \\
\hline Lateral declivity $(\mathrm{H}-\mathrm{cm}: \mathrm{V}-\mathrm{cm})$ & 0.100 & 0.5000 & 0.5467 & 1 & 1 \\
\hline Width $(\mathrm{cm})$ & 25.00 & 24.70 & 28.00 & 14.50 & 16.50 \\
\hline Average width $(\mathrm{cm})$ & 17.35 & 17.18 & 19.80 & 14.50 & 16.50 \\
\hline Breach height / Average width $(\mathrm{cm} / \mathrm{cm})$ & 1.16 & 1.15 & 1.32 & 1.03 & 0.91 \\
\hline
\end{tabular}

of material shape during the failure process, the laser scanner, which is kept in fixed conditions (focal distance and base distance), allows to evaluate the surface by reading the object through equidistant photographs. By this way, variations of the altimetric dimensions are obtained, at each cross section, by tortuosity (curved formations) or by interruption of lines (rectilinear formats). 
Given the distance where the laser is incident to the object and the reflected signal of the object, the images are captured by the webcam and

Where:

$\mathrm{DH}-$ Horizontal distance measured directly by the sliding plate in the direction of the larger dimension of the simulator box, in centimeters;

$\rho_{\text {pixel }} / \mathrm{cm}-$ Density of pixels, i.e. pixels per unit length for different altimetric dimensions, in pixels/cm;

$f(L, C)-2 D$ coordinates of the pixels according to the rows and columns of the image, in centimeters.

The Y-coordinate was obtained for depending on the difference between the capture times, the $3 \mathrm{D}$ image is drawn. Once the surface has been generated after the stipulated time, the sectional

$$
\begin{gathered}
Y=D H \\
X=\rho_{\text {pixel }} / \mathrm{cm} \\
Z=f(L, C)
\end{gathered}
$$

every centimeter during the generation of photographs using a scale coupled to a sliding board. Once the photographs were taken from the moment of rupture, these images were grouped in a program developed in $\mathrm{MatLab}^{\circledR}$ software, which allowed the generation of the $X$ and $Z$ coordinates from the chromatic identification of the laser referring to the red tone present in the generated images. In this way, a cloud of points (around 8000 to 10000 points) registration procedures of the surface generated begins. The coordinates of the points are calculated from Equations (1), (2) and (3).

was produced, which materializes the three-dimensional surfaces when integrated with SURFER 3D ${ }^{\circledR}$ software, subsidizing geostatistical interpolation by the kriging method offered by the Map tool in the "contour map" option and in turn creating the contour maps (See Figure 4). For 3D surface modeling, the surface option was used and the wedge shape was interpreted as a function of the breach geometry and the values of $\mathrm{S}_{\mathrm{U}}$.

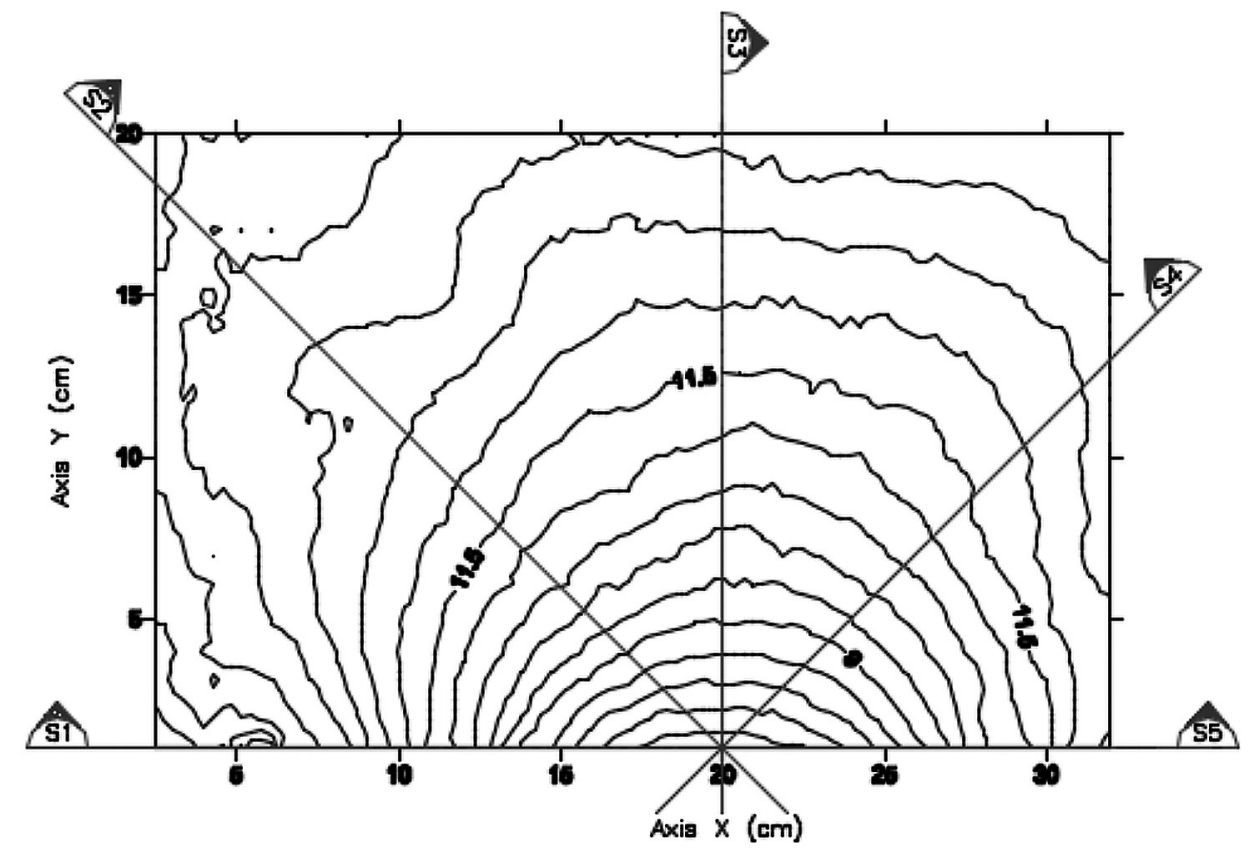

In order to obtain the undrained shear strength $\left(\mathrm{S}_{4}\right)$ of the bentonite in function of the variation of the moisture

content of the liquefied material, box L was used. The equipment was built in acrylic to facilitate the measurement of the
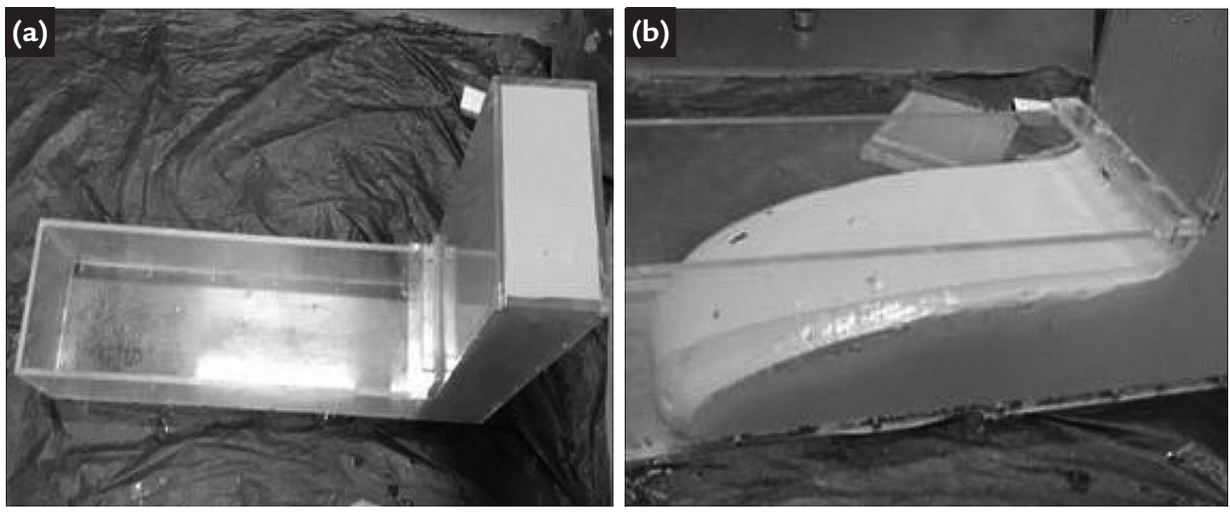

Figure 4

Failure wedge level curves.

horizontal distances from the visualization of the deposition of the sides of the carton, as shown in Figure 5a and $5 \mathrm{~b}$.

Figure 5

a) Box L filled; b) deposition of the tailing in opening the gate. 
The moisture content of the bentonite was changed and the undrained shear strength $\left(\mathrm{S}_{u}\right)$ was calculated based on the modified infinite slope method (see Equa-

Where:

$\mathrm{S}_{\mathrm{u}}$ : undrained shear strength of the material;

$\alpha$ : tailings deposition angle;

$\gamma$ : Specific weight of the material;

$h_{\text {average }}$ : average height of the material.

The bulk unit weight of the mate-

Where:

$\mathrm{V}_{\text {mob. }}$ - Calculated mobilized volume of material;

$A_{\text {top }}$ - Area delimited by the top level curve;

$A_{\text {base }}$ - Area delimited by the base level curve;

E - Vertical distance between base and top levels $(15 \mathrm{~cm})$.

\begin{tabular}{c|c} 
Parameters and properties & Scale Factor (Prototype / small-scale model) \\
\hline Gravity & 1 \\
\hline Length & $\lambda$ \\
\hline Area & $\lambda^{2}$ \\
\hline Volume & $\lambda^{3}$ \\
\hline Force & $\lambda^{3}$ \\
\hline Density & 1 \\
\hline Mass & $\lambda^{3}$ \\
\hline Bulk unit weight & 1 \\
\hline Stress & $\lambda$ \\
\hline Friction angle & 1 \\
\hline Porosity & 1 \\
\hline Elastic modulus & $\Lambda$ \\
\hline Cohesion & $\lambda$ \\
\hline Inertia & $\lambda 4$ \\
\hline
\end{tabular}

The calculation of the parameters of mass releasing in real scale, is based on the

Where:

$\lambda$ - Scale factor;
$\mathrm{H}$ - Height of the dam; $\mathrm{S}_{\mathrm{u}}$ - Undrained shear strength; tion 4), and then validated by the tailings scattering studies of Lazarim (2015). The undrained shear strength $\left(\mathrm{S}_{u}\right)$ is calculated as a function of the soil deposition angle

$$
S_{u}=\gamma \cdot h_{\text {average }} \cdot \cos ^{2} \alpha \cdot \operatorname{tg} \alpha
$$

rial $(\gamma)$ was obtained by filling in a $5 \mathrm{x}$ $5 \times 10 \mathrm{~cm}$ box in a loose state and then weighed using a precision scale, whose value was calculated as a function of the soil weight ratio $\left(P_{\text {soil }}\right)$ and the volume of the box $\left(V_{\text {soil }}\right)$. To calculate the mobilized volume of material from the

$$
V_{\text {mob. }}=\frac{A_{\text {base }}+A_{\text {Top }}}{2} . \mathrm{E}
$$

The top area was generated from the interpolation of the lengths obtained by the average slope of the physical model $(\alpha)$ of each section in the plane referring to the dimension of $15 \mathrm{~cm}$, referenced by the base of the simulation box from the base area.

When the small-scale models are submitted to the non-centrifuged tests (as in presented study), a scale factor must Scale Factor (Prototype / small-scale model) quantities on Table 3. Therefore, the variables of the physical model are converted

$$
\begin{aligned}
& \mathrm{H}_{\text {prototype }}=\lambda \times \mathrm{H}_{\text {model }} \\
& \mathrm{S}_{\text {u prototype }}=\lambda \times \mathrm{S}_{\text {u model }} \\
& \mathrm{V}_{\text {. prototype }}=\lambda^{3} \times \mathrm{V}_{\text {. model }}
\end{aligned}
$$

be applied to the material or equipment characteristics in order to the test corresponds to the prototype. Table 3 lists the scale factors for several parameters, based on the similarity theory. The aspects considered from the similarity theory are similar to those presented in the study by Dell 'Avanzi et al. (2006), Lazarim (2015), Silva (2013) and Souza Junior et al. (2017).

Table 3

Relationship between magnitude and parameters versus scale factor (prototype/small-scale model). (Silva, 2013).

into prototype values from Equations (6), (7) and (8):

V - Volume of released material. 


\section{Discussion}

Several difficulties occurred during the tests for granulometric characterization of sodium montmorillonite. In the study herein presented, the authors preferred to present the granulometric distribution curve obtained in tests performed without deflocculant
(Figure 6), using the laser granulometry measurement technic. The obtained distribution of granulometric fractions of bentonite is: $89.84 \%$ of silt, $8.25 \%$ of sand and $1.91 \%$ of clay. Certainly, those values correspond to the flocculated grains of bentonite. The classification

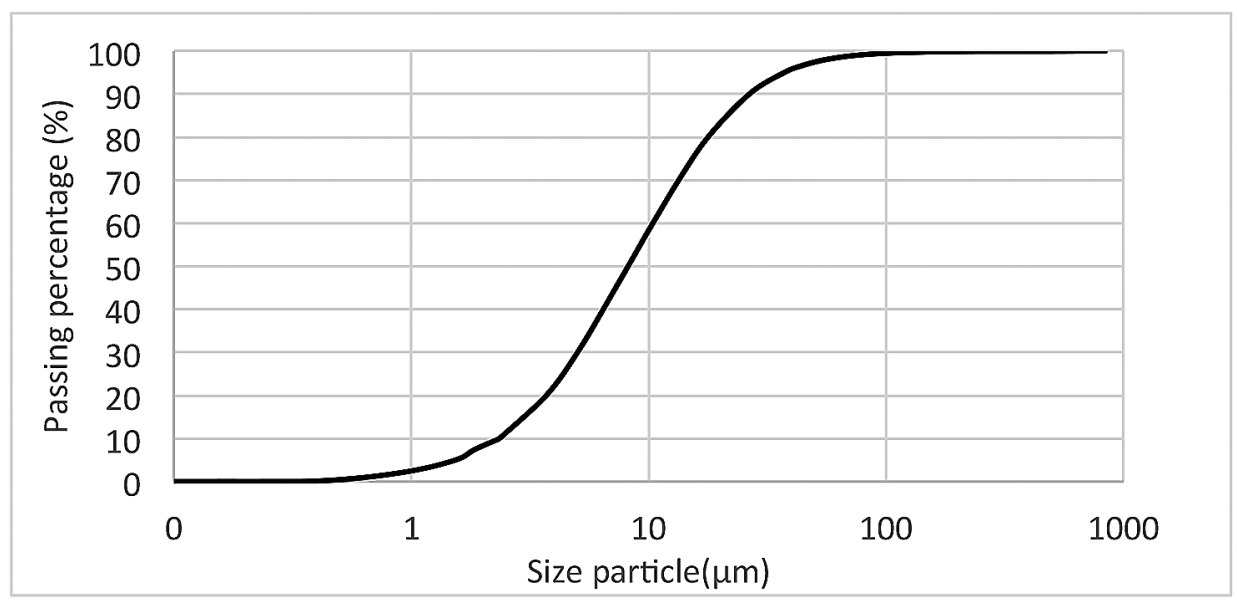

Regarding the undrained shear strength $\left(S_{u}\right)$, that were obtained using the L box test procedures, as

previously described, it was adapted a moisture content range from $890 \%$ to $970 \%$, referring to the

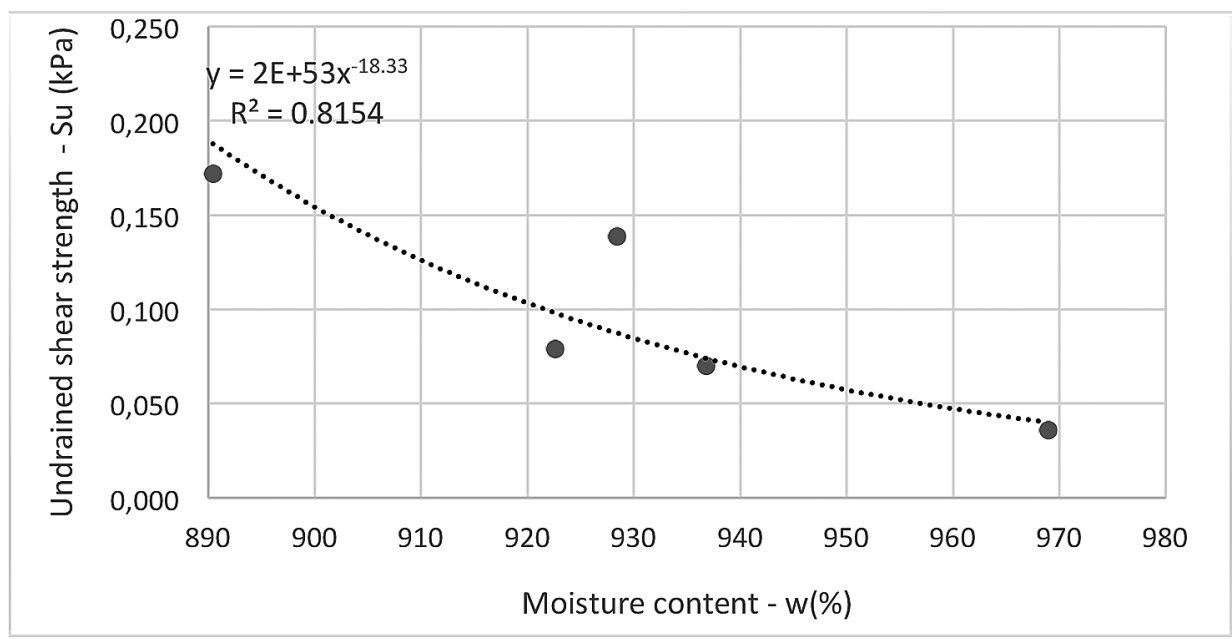

Such values of undrained shear strengths are compatible with those discussed by Olson and Stark (2002) and with the scale 1:500, adopted for the physical model. Olson and Stark (2002) presented a study showing that the undrained shear strength ratio of normally consolidated tailings, $\mathrm{S}_{\mathrm{u}} / \sigma_{\mathrm{vo}}^{\prime}$, ranges from 0.04 to 0.20 , in pre-failure conditions. It represents values of $\mathrm{Su}$ ranging between 0 and $105 \mathrm{kPa}$ in the field and between 0 and $0.21 \mathrm{kPa}$ in the small scale model. After the tailings dam failure, the shear strengths is referred to as liquefied undrained shear strength, with values normally ranging between 1 and $17 \mathrm{kPa}$, as discussed in Lucia (1984).

Using the technique of obtaining undrained shear strength $\left(S_{u}\right)$ as a function of the moisture content $(\mathrm{w} \%)$ in slurry consistency, it was verified that, was increased, the deposition angles of the material decreased and consequently reduced the $\mathrm{Su}$ value of the material.

The relationship between the undrained shear strength $\left(\mathrm{S}_{u}\right)$ and the volume released from the reservoir (V.lib) can be seen in Figure 8. One can note that as the average width of the breach $(\mathrm{Lm})$ increases, a greater volume as the moisture content of the bentonite was generated from the standard NBR 6502 (ABNT, 1995), whose applicable material designation is silt with little sand and traces of clay. This bentonite presents a plasticity index (IP) of higher than $15 \%$, characterizing a material of high plasticity.

Figure 6

Bentonite granulometry test.

range of undrained shear strength $\left(\mathrm{S}_{\mathrm{u}}\right)$ of 0.030 to $0.20 \mathrm{kPa}$, as shown in Figure 7.

Figure 7

Undrained shear strength $\left(\mathrm{S}_{u}\right)$ versus material moisture content (w\%).

of bentonite is mobilized during the tests. Comparing the breach formats, it is possible to notice that the breach geometry influences the mass mobilization. Although the rectangular and trapezoidal breaches allowed the formation of similar wedges, the average widths of the rectangular breaches were smaller, and the values of mobilized mass were superior to the trapezoidal breaches.

Probably, since the measurements of the base widths of the rectangular breaches were greater than the base widths of the trapezoidal breaches, the magnitude of the mobilized mass can be significantly influenced by the size of the 
breach base. In the breaches with slopes 0:50 H: $1 \mathrm{~V}, 0.51: 1 \mathrm{~V}$ and 0: $55 \mathrm{H}: 1$ $\mathrm{V}$, it was noticed that the greater the increase in the average width of the aperture, the greater the mass mobilized.

As for the rectangular breaches B4 and B5, it was noticed that there was a

Figure 8

Results of the post-rupture mobilized mass evaluation of the physical model of tailings reservoir.

With respect to the shape of the wedge in the B1 breach, it was noted that when the undrained shear strength $\left(S_{u}\right)$ value reduces, the slopes of the

Comparison of the mobilization of material mass as a function of the undrainedshear strength $\left(S_{u}\right)$ in breach B1.

As can be seen in Figure 10, in two breaches (B3 and B4) with different geometries and using material with different undrained shear strengths, different wedge formats

Figure 10

Comparison of the mobilization of material mass as a function of the breach geometry. reduction of mobilized mass with the increase of the breach width. In general, in the B5 simulations, the mobilized volumes values were smaller than those on a shorter breach (B4). Possibly, this behavior can be justified by the variation of strains generated after opening the breach. The stress relief generated after formation of the breach allowed the formation of wedges with smaller widths and larger lengths, caused by the stabilization of the slopes of the central sections (S2, S3 and S4) at smaller angles in the breach B5 with respect to the breach B4.

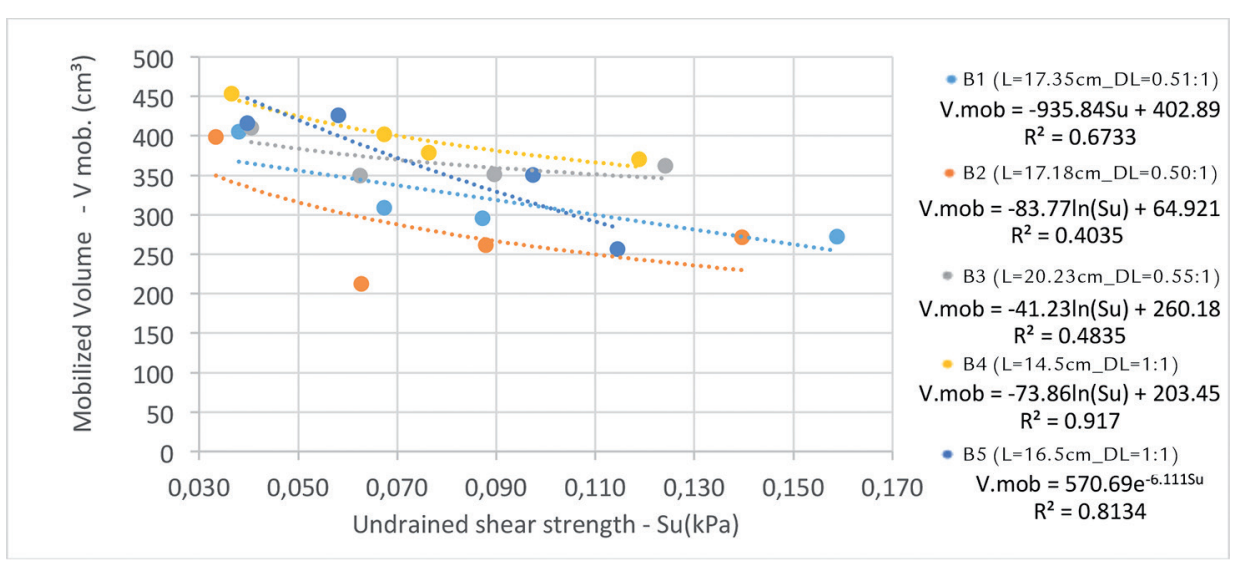

sections reduce as well. In addition, the base height of the deposited material immediately near the breach point increases, as there is an increase in un-

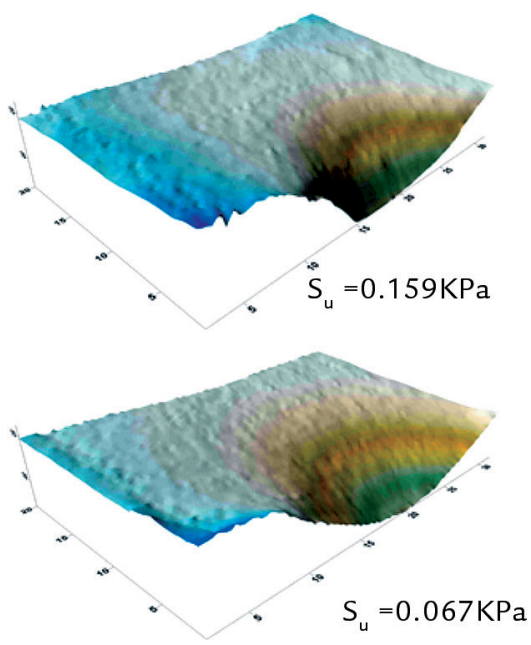

were obtained. In breach 4 (trapezoidal format), the formation of ellipsoidal wedges was observed, which was not observed in breach 3 (rectangular format) that generated wedges with

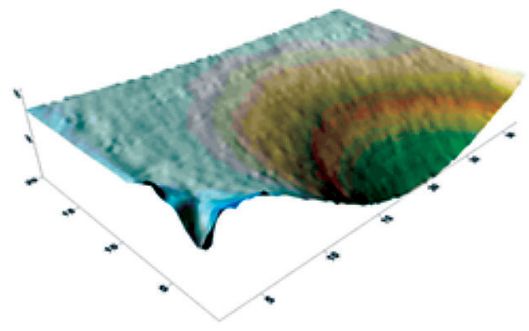

Breach $3-\mathrm{S}_{\mathrm{u}}=0.040 \mathrm{KPa}$ drained shear strength $\left(\mathrm{S}_{\mathrm{u}}\right)$, according to Figure 9. This implies that the more rigid the material, the more superficial the mobilized material.

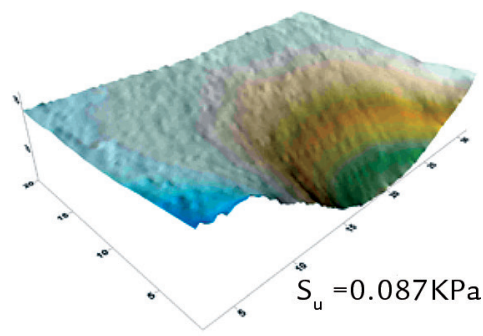

circular shapes. The angles of section S1 and S5 were steeper for breach 3 compared to breach 4 , while sections S2, S3 and S4 presented angles with close values.

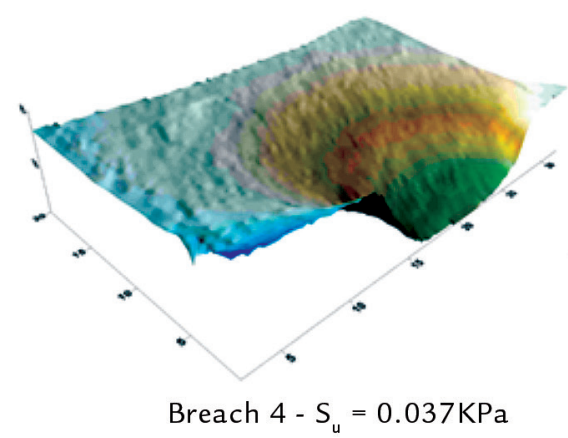




\section{Conclusions}

Herein, regarding the mass mobilization of tailings in the small-scale physical model, the following considerations can be inferred:

- The amount of mobilized material increases with the moisture content of the material, which is dependent on its undrained strengths;

- The lateral slope of the breach influences the amount of post-failure mobilized material;

\section{Acknowledgments}

The authors thank CAPES (Coordination for the Improvement of Higher Education Personnel) for the provision of resources and scholarships;
- In trapezoidal breaches, the amount of mobilized material increased with the average width of breach;

- In rectangular breaches, this behavior was different. At breaches B4 and B5, the trends indicate that for values of $\mathrm{Su}$ lower $0.040 \mathrm{kPa}$, there is an increase in mobilized mass as the breach width increases;

- Wedges whose breaches have higher lateral slopes (near $90^{\circ}$ ) showed steeper slopes, confirming that the slope of the breach exerts influence on the mass mobilization;

- The rectangular breaches, although they had a lower average width in relation to the inclined breaches, induce greater mobilization of the deposited mass, which indicates that the base width, which in the rectangular breaches was larger, has a significant influence on the tailings release. to the Graduate Program in Civil Construction Engineering of the Federal University of Paraná (UFPR) for the provision of laboratory infrastructure and equipment; to the Department of Geomatics of UFPR for the supply of the laboratory structure to carry out the experimental simulations.

\section{References}

ANA. Relatório de Segurança de Barragens 2016. Brasília: ANA, 2017. 156 p. (Relatório Técnico.).

ASSOCIAÇÃO BRASILEIRA DE NORMAS TÉCNICAS (2006). NBR NM 45: agregados: determinação da massa unitária e do volume de vazios. Rio de Janeiro, 2006.

ASSOCIAÇÃO BRASILEIRA DE NORMAS TÉCNICAS. NBR 6459: determinação do limite de liquidez. Rio de Janeiro, 2016.

ASSOCIAÇÃO BRASILEIRA DE NORMAS TÉCNICAS. NBR 6502: Rochas e Solos. Rio de Janeiro,1995.

ASSOCIAÇÃO BRASILEIRA DE NORMAS TÉCNICAS (2016). NBR 7180: Determinação do limite de plasticidade. Rio de Janeiro, 2016.

DEPARTAMENTO NACIONAL DE ESTRADAS DE RODAGEM. DNER-ME 093/94: Dolo-Determinação da densidade real dos grãos. Distrito federal, 1994.

DEPARTAMENTO NACIONAL DE ESTRADAS DE RODAGEM. DNER-ME 213/94: Solo-Determinação do teor de umidade. Distrito federal, 1994.

AZAM, S., LI, Q. Tailings dam failures: a review of the last one hundred years. Waste Geotechnics, Regina, s/v., s/nº, p. 50-53, 2010.

BRUNNER, G. Using hec ras for dam break studies. Davis: USACE, 2014.62p. (Technical manual).

DAVIES, M. P. Tailings impoundment failures: are Geotechnical Engineers Listening. Waste Geotechnics, Regina, s/v., s/n., p. 31 -36, 2002.

DELL'AVANZI, E., GODOY, H., BERNARDES, G. P., JARROUGE, H. Estudo do comportamento de estruturas grampeadas utilizando modelos reduzidos - conceitos teóricos para garantia da similitude modelo-protótipo. In: CONGRESSO BRASILEIRO DE MECÂNICA DOS SOLOS E ENGENHARIA GEOTÉCNICA, 13. Curitiba, 2006.

ICOLD. Tailings dams risk of dangerous occurrences: lessons learnt from pratical experiences. Paris: ICOLD, 2001. 144p. (Boletim 121).

FLOODLIST. Disponível em: http://floodlist.com/africa/merriespruit-tailings-dam. Acesso em: 13 Mar. 2018.

FROELICH, D.C. Embankment dam breach parameters and their uncertainties. Journal of Hydraulic Engineering, v. 134, n. 12, p. 1708-1721, 2008.

LAZARIM, T. P. Espalhamento de rejeitos em cenários de ruptura de barragens simulações em modelo reduzido e proposta de avaliação de área atingida. Curitiba: Programa de Pós-graduação em Engenharia Civil, Universidade Federal do Paraná, 2015. (Dissertação de Mestrado).

MACDONALD, T. C., LANGRIDE-MONOPOLIS, J. Breaching characteristics of dam failures. Journal of Hydraulic Engineering, v. 110, n. 5, p. 567-586,1984. 
MINNING. Disponível em: http://www.mining.com/why-samarco-tailings-dam-failed/. Acesso em: 13 Mar. 2018.

OLSON, S. C., STARK, T. D. Liquefied strength ratio from liquefaction flow failure case histories. Journal Canadian Geotechnical, v. 39, s/n., p. 629-647, 2002.

PORTAL BRASIL. Setor mineral representa 4\% do PIB brasileiro. Brasília, 2014 em: <http://www.brasil.gov.br/infraestrutura/2014/12/setor-mineral-representa-4-por-cento-dopib-brasileiro>. Acesso em: 23 Abr. 2016

RICO, M., BENITO, G., SAlGUEIRO, A. R., DÍEZ-HERRERO, A., PEREIRA, H. G. Reported tailings dam failures: the European incidents in the worldwide context. Journal of Hazardous Materials, v. 152, n. 1-3, p. 846-852, 2008.

SILVA, D. R. de P. Avaliação da contribuição de sistemas de fraturas nas condições de fluxo e estabilidade de encostas. Curitiba: Programa de Pós-graduação em Engenharia de Construção Civil, Universidade Federal do Paraná, 2013. (Dissertação de Mestrado).

SOUZA JUNIOR, T. F. S., MACHADO, A. M. L., CENTENO, J. A. S., LUZ, C. C., TEIXEIRA, S. H. C. Método de levantamento de transferência de material rompido através de modelo físico de barragem - aplicação da técnica de triangulação a laser. Revista Brasileira de Cartografia (Online), Rio de Janeiro, v. 69, p. 1163-1174, 2017.

Received: 6 July 2018 - Accepted: 28 January 2019. 